\title{
KOMUNIKASI PEMBANGUNAN UNTUK IDENTITAS TEMPAT: BUDAYA KAMPUNG DI KOTA SEMARANG
}

\section{Development Communication for Place Identity: Village Culture in the City of Semarang}

\author{
Arifa Rachma Febriyani ${ }^{1, *)}$, Fibriyani Nur Aliya ${ }^{2)}$ \\ ${ }^{1}$ Program Studi D-III Hubungan Masyarakat, Sekolah Vokasi, Universitas Diponegoro, Semarang 50275, Indonesia \\ ${ }^{2}$ Program Studi Ilmu Komunikasi, Fakultas Ilmu Komputer, Universitas Dian Nuswantoro, Semarang 50131, Indonesia \\ ${ }^{*}$ E-mail: arifafebriyani@ lecturer.undip.ac.id
}

\section{ABSTRACT}

Development has caused the cut down of villages with historical and cultural values as the identity of Semarang City. Using the Pentahelix Model, this study aims to determine how stakeholders of Semarang city maintain the cultural values of villages as the identity of Semarang City. The study uses a qualitative descriptive approach. Interviews and documentation are chosen as data collection techniques. The results showed that the government, community, private sector, academia, and media had played an active role in constructing the identity of Semarang City. However, each stakeholder has its own approaches in constructing the identity of Semarang City. Collaboration between stakeholders still needs to be improved so that there is mutual understanding regarding the definition and approaches in constructing the identity of Semarang City.

Keywords: City Branding, Development Communication, Penthahelix Model, Place Identity, Village Culture

\begin{abstract}
ABSTRAK
Pembangunan menyebabkan semakin hilangnya Kampung-kampung yang sarat nilai sejarah dan budaya sebagai identitas Kota Semarang. Menggunakan Model Pentahelix, penelitian ini bertujuan untuk mengetahui bagaimana elemen kota mempertahankan budaya kampung sebagai identitas Kota Semarang. Penelitian menggunakan pendekatan deskriptif kualitatif. Teknik pengumpulan data yang digunakan adalah wawancara dan dokumentasi. Hasil penelitian menunjukkan bahwa pemerintah, komunitas, swasta, akademisi, dan media telah berperan aktif. Meski demikian kolaborasi antar elemen masih perlu ditingkatkan, sehingga mampu memunculkan sinergitas dari setiap langkah yang diambil.
\end{abstract}

Kata Kunci: Kota, Komunikasi Pembangunan, Model Pentahelix, Identitas tempat, Budaya Kampung

Content from this work may be used under the terms of the Creative Commons Attribution-ShareAlike

4.0 International License. Any further distribution of this work must maintain attribution to the author(s) and the title of the work, journal citation and DOI.

Published under Department of Communication and Community Development Science, IPB University ISSN : 1693-3699 | EISSN : 2442-4102 


\section{PENDAHULUAN}

Semarang sebagai ibukota Provinsi Jawa Tengah terus berbenah menjadi sebuah kota yang indah. Pertengahan tahun lalu, Kota Semarang berhasil meraih penghargaan dari Kementerian PPN/Bappenas sebagai kota terbaik tingkat nasional dengan kategori "Kota dengan Perencanaan dan Pencapaian Terbaik Tingkat Kota" dan "Kota dengan Pembangunan Infrastruktur Daerah Skema KPBU” (Dani \& Hidayat, 2019).

Semarang sebagai kota multikultural, dibuktikan dengan adanya beberapa etnis yang tinggal di Kota Semarang. Selain Etnis Jawa, ada pula Etnis Tionghoa, Etnis Melayu, Etnis India, dan Etnis Arab. Keberagaman etnis tersebut juga telah memberikan sumbangsih bangunan-bangunan yang sarat sejarah. Sebagai contoh, adanya bangunan masjid, gereja, klenteng, dan vihara yang menjadi peninggalan masa lampau, di mana saat ini niscaya sebagai wujud kearifan lokal. Meski Semarang bersifat multikutural, tidak ada budaya yang lebih dominan dan menjadikan budaya lain inferior. Semua budaya memiliki tempat yang sama, tidak saling menegasi ataupun menyakiti. Melihat pada kekayaan budaya dan keberagaman etnis yang disertai bangunan-bangunan bernilai sejarah, Kota Semarang semakin menjadi incaran untuk berwisata, di mana kemudian juga menarik para investor.

Nilai investasi yang masuk ke Kota Semarang pada semester pertama tahun 2019 mencapai Rp. 15,94 triliun. Angka tersebut tidak hanya diperoleh dari Penanaman Modal Dalam Negeri (PMDN), tetapi juga Penanaman Modal Asing (PMA). Diketahui pula sektor yang paling diminati adalah sektor konstruksi, perumahan, kawasan industri dan perkantoran (Pujakesuma, 2019). Berdasarkan data tersebut, muncul ungkapan "Semarang menuju rimba pencakar langit". Tidak hanya gedung perkantoran dan pusat bisnis, investor juga tertarik untuk mengembangkan bisnis apartemen dan kondominium.

Dapat diketahui bahwa pembangunan infrastruktur di Kota Semarang begitu pesat. Hal ini kemudian secara bertahap mengancam hilangnya kampung asli di Kota Semarang, Jawa Tengah (Damanik, 2016). Penyebab hilangnya kampung-kampung tersebut adalah penggabungan dengan kelurahan lain dan adanya pembangunan hotel, mall, dan apartemen.

Salah satu kampung yang memiliki nilai sejarah dan hilang adalah Kelurahan Melayu Darat. Kampung yang dulunya terkenal dengan sosok Kiai Darat ini, kini berubah menjadi Kelurahan Dadapsari. Adapun beberapa kampung lain yang telah hilang dari peta Kota Semarang karena penggabungan dengan Kampung lain adalah Kelurahan Bergota yang menjadi Kelurahan Randusari dan kelurahan Lemah Gempal yang bergabung dengan Kelurahan Barusari (Fajlin, 2019).

Meski demikian, hal tersebut dianggap tidak menghilangkan budaya kampung yang dimiliki karena yang terjadi hanya perubahan nama yang bersifat administratif. Pemberi dampak terbesar hilangnya budaya kampung adalah desakan pembangunan oleh investor. Beberapa kampung yang hilang di antaranya Kampung Jayengjatan, Kampung Basahan, Kampung Morojayan, Petroos, Mijen. Kampung-Kampung asli ini hilang karena tergusur oleh pembangunan mall, hotel, dan pabrik. Kondisi ini dapat dimaknai dengan hilangnya kampung tersebut, maka hilang pula budaya yang dimilikinya.

Beberapa kampung yang sarat nilai sejarah dan masih bertahan hingga saat ini adalah Kampung Kauman, Kampung Pecinan, Kampung Belanda, dan Kampung Melayu. Kampungkampung ini dinilai telah menjadi peradaban budaya bahkan menjadi pusat wisata sejarah dan budaya di Kota Semarang (Cecilia, 2016).

Meski demikian, SK Walikota Semarang No. 050/801/2014 mencantumkan nama kampungkampung tersebut dalam daftar kampung kumuh dan masuk dalam program Kotaku. Program Kotaku bertujuan untuk mendampingi dan membangun infrastruktur dalam upaya mengurangi intensitas kumuh. Saat ini, total kampung kumuh di Kota Semarang adalah sebanyak 62 kelurahan dari 177 kelurahan yang ada (Bappeda Pemkot Semarang, 2019). Berdasar pada kondisi tersebut, dapat disimpulkan bahwa Pemerintah Kota Semarang memiliki tantangan dalam pengentasan kampung dari kekumuhan, tanpa menghilangkan budaya kampung tersebut. Di lain pihak, pemerintah memiliki tanggung jawab utama dalam melestarikan budaya setempat. 
Presiden Indonesia mengatakan bahwa pembangunan infrastruktur fisik dan perubahan tata kota merupakan bagian dari pembangunan peradaban (Rhismawati, 2018). Di sisi lain, banyak ahli mengungkap bahwa pembangunan sering tidak memiliki strategi kebudayaan yang jelas dan konsisten, atau bukan termasuk dalam strategi peradaban untuk memajukan seluruh bangsa. Bukan hanya kian menciptakan disparitas ekonomi, pembangunan juga dinilai telah memunculkan kesenjangan sosial-budaya dan peradaban di antara suku-suku bangsa (Azra, 2015). Hal ini selaras dengan yang disampaikan oleh Gubernur Jawa Tengah, H. Ganjar Pranowo, S.H., M.I.P bahwa dalam menghadapi benturan-benturan peradaban yang kencang ini, masyarakat mesti punya pegangan yang paling kuat dan berkompromi atas budaya yang dimiliki, khususnya untuk masyarakat Jateng dan Semarang (Humas Pemprov Jawa Tengah, 2019).

Penelitian terdahulu mengungkap bahwa sinergi antar pemangku kepentingan yang merujuk pada Model Triple helix plus one menjadi salah satu faktor penentu dalam pembangunan identitas kota. Penelitian tersebut menjelaskan bahwa kerja sama antara pemerintah, perguruan tinggi, dunia usaha, dan komunitas atau masyarakat memiliki andil dalam upaya memperkuat identitas Kota Bogor dengan atributnya sebagai heritage, green, dan smart city melalui kampanye We Love Bogor di Instagram (Annas \& Irwansyah, 2008). Selaras dengen penelitian Yuningsih, Darmi, \& Sulandari (2019) yang mengemukakan bahwa dalam Model Pentahelix terdapat lima elemen yang menjadi aktor pembangun identitas kota, yaitu pemerintah, akademisi, swasta, komunitas, dan media.

Hal ini diperkuat oleh bunyi Pasal 2 huruf (h) Undang-Undang No. 11 Tahun 2010 tentang Cagar Budaya (UUCB) yang menyatakan bahwa setiap anggota masyarakat didorong untuk berperan aktif dalam pelestarian cagar budaya (Winarni, 2018). Berdasar hal tersebut, dapat diartikan bahwa upaya mempertahankan identitas kota tidak hanya menjadi tanggung jawab pemerintah saja, melainkan seluruh elemen kota. Berikut gambar model Pentahelix yang diajukan dalam penelitian ini, didasarkan pada penelitian terdahulu.

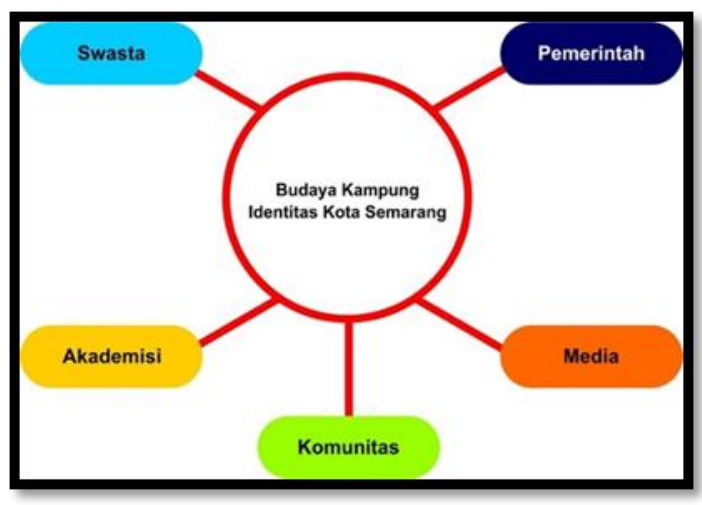

Gambar 1. Model Pentahelix

Peran aktif kelima elemen tersebut dalam upaya mempertahankan identitas kota merupakan hal yang semestinya dilakukan karena budaya dipandang sebagai konstitutif dari identitas lokal dan kualitas hidup serta sektor kompetitif tersendiri (Rizzo \& Throsby, 2006). Sektor pelestarian budaya dianggap memiliki dampak yang sangat luas pada pariwisata, kreatifitas, dan inovasi (Pratt, 2011), bahkan pada pertumbuhan kota terkait regenerasi dan kesejahteraan kota (Evans, 2009), sehingga budaya dapat diartikan sebagai nilai yang menjadikan sebuah kota memiliki jati diri (Montalto, Tacao Moura, Langedijk, \& Saisana, 2019). Berdasar hal tersebut, budaya merupakan faktor yang sangat penting, karena merupakan identitas yang digunakan sebagai dasar pembangunan sebuah kota.

Keunikan suatu tempat tercermin dari kepribadian (place identity) yang membuat suatu tempat memiliki kesan otentik di benak publik, sehingga berbeda dari tempat lainnya. Kota Milan misalnya, menurut Indeks Kota Anholt lekat dengan citranya sebagai kota mode, desain, surga belanja, dan mencerminkan gaya hidup para perancang busana kelas dunia. Kota tersebut menempati 
peringkat kedua destinasi wisata di Italia sebagai jujukan para turis (Carlo, Canali, Pritchard, \& Morgan, 2009).

Identitas tempat (place identity) juga dipandang sebagai seperangkat jaringan asosiasi di benak publik berdasarkan ekspresi visual, verbal, dan perilaku terhadap suatu tempat, yang diwujudkan melalui tujuan, komunikasi, nilai-nilai, perilaku, dan budaya umum dari para pemangku kepentingan (Braun, Kavaratzis, \& Zenker, 2013). Lebih rinci, identitas tempat dijelaskan memiliki sejumlah elemen dasar, meliputi citra tempat, material (bangunan, jalan, alun-alun, dan lainnya), lembaga (undang-undang, peraturan, organisasi, dan lainnya), serta orang-orang dan praktik mereka (tradisi, tindakan berulang, kehidupan sehari-hari, dan lainnya (Kavaratzis \& Kalandides, 2015). Pemahaman ini selaras dengan pernyataan bahwa budaya tempat (place culture) merupakan cara hidup yang dialami dan diciptakan oleh sekelompok orang yang tinggal di suatu tempat, yang selanjutnya membentuk aspek internal dari identitas tempat (place identity) (Kavaratzis \& Hatch, 2013; Kavaratzis \& Kalandides, 2015). Model Dinamika Place Branding juga menjelaskan keterlibatan masyarakat setempat (komunitas lokal) untuk menggarisbawahi kebutuhan dan keinginan mereka terhadap place branding (Kavaratzis \& Kalandides, 2015).

Upaya untuk mempertahankan suatu identitas tempat (place identity) erat kaitannya dengan keterlibatan aktif masyarakat atau komunitas yang menunjukkan penghormatan terhadap budaya lokal dan lingkungannya. Ditinjau dari Model Partisipatif (participatory model), masyarakat dipandang sebagai aktor yang berperan aktif dalam pembangunan dan budaya lokal merupakan suatu aspek yang dihormati (Sarvaes, 2003). Hal ini dapat diamati dari semangat komunitas untuk menjunjung budaya dan lingkungan mereka. Komunikasi dua arah (dialog) untuk menciptakan makna bersama tentang tujuan pembangunan menjadi ciri khas model ini.

Selaras dengan pernyataan tersebut Hadiyanto (2008) menguraikan konsep komunikasi pembangunan partisipatif yang dimaknai sebagai aktivitas yang direncanakan berdasarkan pada proses-proses partisipatif di satu sisi, dan pemanfaatan media komunikasi dan komunikasi tatap muka di sisi lain. Tujuan dari komunikasi pembangunan partisipatif adalah untuk memfasilitasi dialog di antara pemangku kepentingan yang berbeda, yang berkisar pada perumusan masalah atau sasaran pembangunan bersama, mengembangkan dan melaksanakan atau menjabarkan seperangkat aktivitas yang memberi kontribusi untuk mencari solusi yang didukung bersama. Pernyataan dari kedua pakar tersebut mengerucut pada keterlibatan aktif masyarakat (komunitas) dan pemangku kepentingan lainnya untuk bersinergi mengawal dan mendukung pembangunan, termasuk upaya mempertahankan identitas tempat (place identity).

Berpijak pada uraian di atas, identitas tempat (place identity) tentu memiliki arti penting bagi pembangunan daerah. Identitas tempat tidak hanya mempersatukan masyarakat melalui sebuah ikatan emosional, sehingga mereka membangun rasa memiliki (sense of belonging) terhadap suatu daerah. Selaras dengan pernyataan (Nunkoo \& Gursory, 2012; Wang \& Chen, 2015) , identitas tempat juga mampu membentuk sikap masyarakat untuk mendukung pengembangan pariwisata di daerah mereka, yang pada gilirannya dapat mendongkrak perekonomian. Hal ini diperkuat pula melalui temuan Freire (2009) di Algavre dan Costa del Sol bahwa sikap ramah warga menjadi elemen penting untuk mengevaluasi suatu merek tempat (place brand).

Masih sedikit penelitian yang mengungkapkan proses komunikasi dalam membangun identitas tempat sebagai bentuk dari komunikasi pembangunan. Konteks identitas tempat dalam komunikasi pembangunan dilihat sebagai sarana bagi masyarakat untuk secara partisipatif membangun tempat tinggalnya, termasuk didalamnya membangun norma dan gaya hidup (Lalli, 1992), membangun simbol-simbol (Hayden \& Sevin, 2012), hubungan antar manusia, dan pola komunikasinya (Giovanardi, Lucarelli, \& Pasquinelli, 2013) demi mencapai kesejahteraan setempat. Penjelasan sebelumnya telah memperlihatkan bagaimana proses pembangunan identitas tempat seringkali hanya dibahas dari perspektif hubungan masyarakat dan/atau branding. Dengan adanya kekurangan pembahasan identitas tempat dari perspektif komunikasi pembangunan, penelitian ini bertujuan untuk mengetahui bagaimana peran seluruh elemen masyarakat dalam upaya mengkomunikasikan budaya kampung sebagai identitas tempat Kota Semarang di tengah pembangunan infrastruktur fisik yang terus dilakukan. 


\section{METODE}

Penelitian ini menggunakan pendekatan kualitatif dengan tipe penelitian deskriptif. Hal ini bertujuan untuk menguraikan tentang suatu objek sebagaimana adanya dalam waktu tertentu. Data yang diperoleh melalui interview dan dokumentasi dipaparkan secara rinci (Pambudi, 2014; Yuningsih et al., 2019). Pengambilan sampel menggunakan teknik non random sampling dengan kriteria inklusi, dimana peneliti berhak menentukan sampel yang diinginkan berdasar pada tujuan penelitian (Sugiarto, Siagian, Sunaryanto, \& Oetomo, 2003). Adapun sampel yang diinterview adalah Badan Perencanaan Pembangunan Daerah (Bappeda) Kota Semarang bagian infrastruktur, pendiri platform Peka Kota Hub, dan CV. Bersukaria Tour. Pencarian data pendukung, peran yang dilakukan oleh elemen kota akademisi, dan media dilakukan melalui dokumentasi. Diperoleh data sekunder dari Bappeda Kota Semarang berwujud layout perencanaan lokasi cagar budaya, jurnal ilmiah, artikel terkait objek yang diteliti, baik dari media elektronik, cetak, maupun media sosial dan artikel yang bersumber dari internet.

Teknik pengumpulan data melalui wawancara semi-terstruktur dengan menggunakan panduan wawancara (interview guide) yang memuat pokok-pokok pertanyaan. Dengan teknik ini, peneliti memiliki kesempatan lebih luas untuk melakukan penggalian informasi melalui pertanyaan pendalaman. Sedangkan teknik dokumentasi dilakukan dengan pengelompokan artikel berdasar pada masing-masing elemen pentahelix.

Analisis data menggunakan tahap kondensasi data, verifikasi data, dan konklusi data. Adapun validasi data menggunakan triangulasi sumber, sehingga mampu menguatkan teori, metode, dan interpretasi penelitian (Yin, 2009). Fenomena yang diteliti adalah upaya yang dilakukan oleh elemen kota, yang didasarkan pada Model Pentahelix, guna mempertahankan budaya kampung sebagai identitas Kota Semarang.

\section{HASIL DAN PEMBAHASAN}

\section{Kota Semarang}

Usia Kota Semarang yang menginjak 472 tahun menandakan bahwa kota tersebut dapat dikatakan matang dalam hal pembentukan identitas tempat. Sebagaimana pandangan para pakar tentang identitas tempat yang telah diulas, setiap kota pun memiliki kepribadian unik yang membuatnya berbeda dengan kota lainnya. Identitas kota terbentuk dari pemahaman dan pemaknaan citra (image) tentang sesuatu yang ada atau pernah ada/melekat pada kota atau pengenalan obyekobyek fisik (bangunan dan elemen fisik lain) maupun obyek non fisik (aktivitas sosial) yang terbentuk dari waktu ke waktu. Aspek historis dan pengenalan image yang ditangkap oleh warga kota menjadi penting dalam pemaknaan identitas kota atau citra kawasan (Wikantiyoso, 2009; Amar, 2009).

Sejumlah bangunan bersejarah yang telah diklaim sebagai cagar budaya, diantaranya adalah Gereja Protestan Indonesia Barat Immanuel atau yang lebih dikenal sebagai Gereja Blenduk di kawasan Kota Lama. Gedung ini merupakan salah satu contoh obyek fisik (aspek tangible) yang turut menentukan identitas kota. Sebutan "Little Netherland" yang melekat untuk kawasan Kota Lama adalah bukti bahwa publik - baik warga kota maupun wisatawan luar-membentuk citra tentang Kota Semarang. Obyek fisik lainnya yang menentukan identitas kota adalah keberadaan kampung-kampung di Kota Semarang, seperti Kampung Sekayu yang diyakini sebagai kampung tertua di mana di dalamnya berdiri masjid kuno bernama "Masjid At-Taqwa", Kampung Kauman yang dahulu sebagai pusat budaya Islam dan simbol perdagangan maju, Kampung Melayu, Kampung Bustaman, Kampung Kranggan, dan beberapa kampung lainnya (Asdhiana, 2016). Keragaman budaya lokal yang lahir dan tumbuh di sana dan interaksi sosial antar warga kampung merupakan obyek non fisik (intangible) yang juga menentukan identitas kota.

Tedi Kholiludin mengemukakan bahwa Kota Semarang memiliki kekhasan dalam pengelolaan kemajemukan budaya. Menurutnya, tidak ada satu budaya yang dominan dan menjadikan budaya lainnya sebagai inferior. Tedi mengkaji bahwa kebudayaan santri, Tionghoa, dan Jawa berada dalam satu panggung bersama yang tidak terlampau intens dalam berdialog, tetapi juga tidak saling 
menegasikan. Kehidupan multietnis yang terjalin sejak ratusan tahun lalu membuat Kota Semarang dinilai sesuai untuk memantapkan identitas kotanya sebagai "tuan rumah budaya". Identitas kota tersebut tercermin pula dari keberadaan beberapa tempat ibadah bersejarah yang juga menjadi destinasi wisata, seperti Masjid Agung "Kauman" Semarang, Masjid Agung Jawa Tengah, Gereja Blenduk, Kelenteng Sampookong, dan Vihara Buddhagaya Watugong, yang menunjukkan bahwa warga kota hidup berdampingan secara harmoni, meskipun mereka berbeda agama dan latar belakang budaya.

\section{Peran Pemerintah}

Peran Pemerintah Kota Semarang dalam upaya mempertahankan budaya kampung sebagai identitas kota adalah dengan mengeluarkan SK Wali Kota Semarang Nomor 640/395 Tahun 2018 tentang Penetapan Status Cagar Budaya Kawasan Kota Lama Semarang. Melalui surat keputusan tersebut, terdapat 128 bangunan di kawasan Kota Lama yang ditetapkan sebagai cagar budaya, meskipun sebagian besar bangunan cagar budaya itu hingga kini masih digunakan untuk melangsungkan aktivitas bisnis, seperti restoran dan kafe, bank, gedung cabang BUMN di daerah, BUMD, dan perusahaan swasta. Penerbitan surat keputusan tersebut menunjukkan komitmen pemerintah untuk melindungi bangunan cagar budaya sebagai komponen fisik (tangible) yang penting untuk membentuk dan atau mempertahankan identitas kota, di tengah pesatnya pembangunan fisik.

Pihak Bappeda Pemerintah Kota Semarang, menyampaikan:

"Pemerintah tidak akan mengambil kebijakan pembangunan yang berdampak pada penghilangan budaya, karena hal tersebut merupakan salah satu jati diri kota. Tindakan yang justru dilakukan adalah dengan mengeluarkan peraturan tentang cagar budaya, agar identitas kota tetap lestari",.

Peran pemerintah juga diwujudkan dari pencanangan pendampingan Program Kotaku terhadap kawasan kumuh yang dilandasi oleh penerbitan SK Wali Kota Semarang Nomor 050/801/2014 tentang Penetapan Lokasi Lingkungan Perumahan dan Permukiman Kumuh Kota Semarang. Pada awal pelaksanaan, lokasi permukiman kumuh seluas 415,83 hektare meliputi 62 kelurahan dari total 177 kelurahan di Kota Semarang. Kategorisasi permukiman kumuh didasarkan pada sejumlah kriteria, seperti aspek bangunan gedung (ketidakteraturan; kepadatan; dan ketidaksesuaian dengan persyaratan teknis bangunan), aspek kondisi jalan lingkungan, aspek kondisi penyediaan air minum, aspek kondisi drainase, aspek kondisi pengelolaan air limbah, aspek kondisi pengelolaan persampahan, dan aspek kondisi proteksi kebakaran. Hingga akhir tahun 2018, luas permukiman kumuh di Kota Semarang telah berkurang secara signifikan, yaitu menjadi 148,29 hektare.

Berdasar Rencana Pembangunan Jangka Menengah Daerah (RPJMD) pada tahun 2020 ditargetkan menuju Kota Semarang bebas kumuh, dengan rata-rata target pengurangan kumuh dalam periode 2018 hinga 2020 mencapai 95,32 Ha. Kawasan kumuh perlu memeroleh perhatian dan penanganan khusus dari pemerintah agar dapat segera dilakukan pembenahan lingkungan sehingga terwujud wajah kota yang cantik di berbagai daerah. Mengingat pada Model Dinamika Place Branding dijelaskan bahwa place branding yang efektif berkaitan pula dengan pembentukan citra publik (impressing) terhadap suatu tempat (Kavaratzis \& Hatch, 2013). Dengan demikian, lingkungan fisik yang bersih dan indah merupakan syarat untuk mempertahankan identitas kota, sekaligus membentuk citra publik yang positif terhadap Kota Semarang.

Selain menerbitkan regulasi tentang penetapan cagar budaya dan permukiman kumuh, Pemerintah Kota Semarang juga mengikuti Lomba Habitat yang diadakan oleh Pemerintah Provinsi Jawa Tengah. Mengusung tema "Menata Kampung Kumuh Membangun Branding Kawasan" Kota Semarang memperoleh juara harapan tiga. Upaya penanganan kumuh diajukan sebagai materi lomba dengan konsep eksotika, yaitu dengan menyinergikan perencanaan pembangunan dengan kawasan world heritage. Langkah ini diambil dengan perencanaan Kota Lama sebagai world heritage melalui perencanaan DED Kali Semarang, dan Perencanaan Kawasan Sleko Menara Syahbandar bekerjasama dengan PT. PGN. Kemudian menciptakan linkage Kawasan Heritage Semarang yaitu Kota Lama, Masjid Layur, Kampung Melayu, Sleko Menara Syahbandar dan Pecinan melalui Kali (sungai) 
Semarang. Konsep eksotika Kampung Tua juga dilakukan dengan tetap mempertahankan bangunanbangunan yang memiliki nilai historis dan menjaga kampung tua. Kegiatan-kegiatan yang terintegrasi juga akan dilakukan guna menunjang Kawasan PUSAKA.

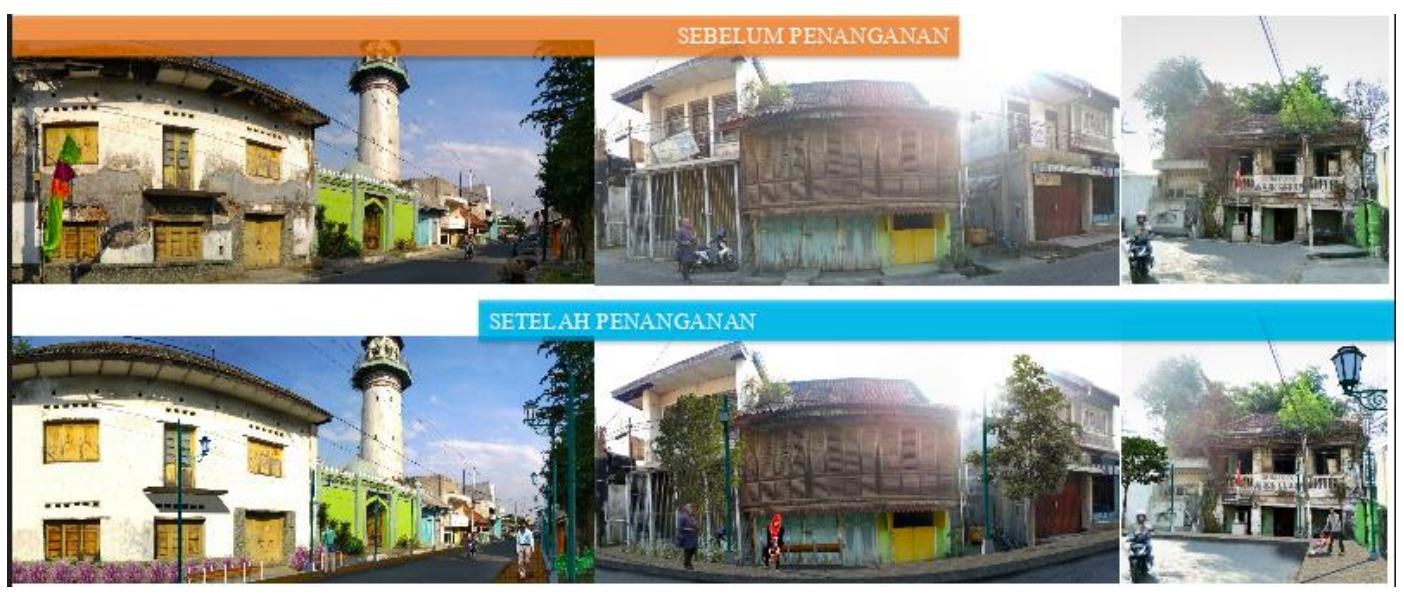

Sumber: Bappeda Kota Semarang, 2019

Gambar 2. Progress Pembangunan Kampung Melayu

Gambar 2 menunjukkan pembangunan Kampung Melayu mulai dari penataan fasade dan pedestrian hingga peremajaan aspal jalan. Melalui gambar ini dapat diketahui bahwa pemerintah Kota Semarang tidak hanya mengatasi masalah kumuh kampung yang kaya nilai budaya ini, namun juga memperindah tampilannya tanpa menghilangkan bangunan-bangunan yang sarat sejarah.

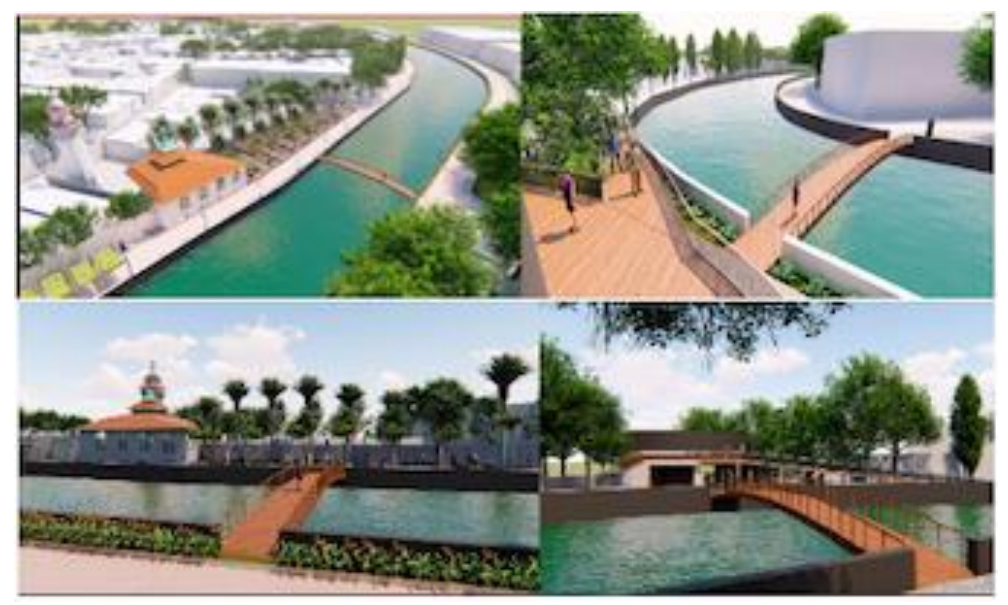

Sumber: Bappeda Kota Semarang, 2019

Gambar 3. Rencana Penanganan Kawasan

Gambar 3 menunjukkan gambaran upaya yang akan dilakukan Pemerintah Kota Semarang dalam mensinergikan kampung-kampung yang sarat budaya dan nilai sejarah. Jembatan dan pedestrian akan dibangun untuk menghubungkan Masjid Layur, Kampung Melayu, Menara Syahbandar, dan Kota Lama. Melalui perencanaan ini dapat dilihat bahwa pemerintah tidak hanya berfokus pada penanganan kumuh dan peremajaan tampilan, tetapi menambah nilai jajaran kampung budaya dengan menjadikannya saling terhubung. 


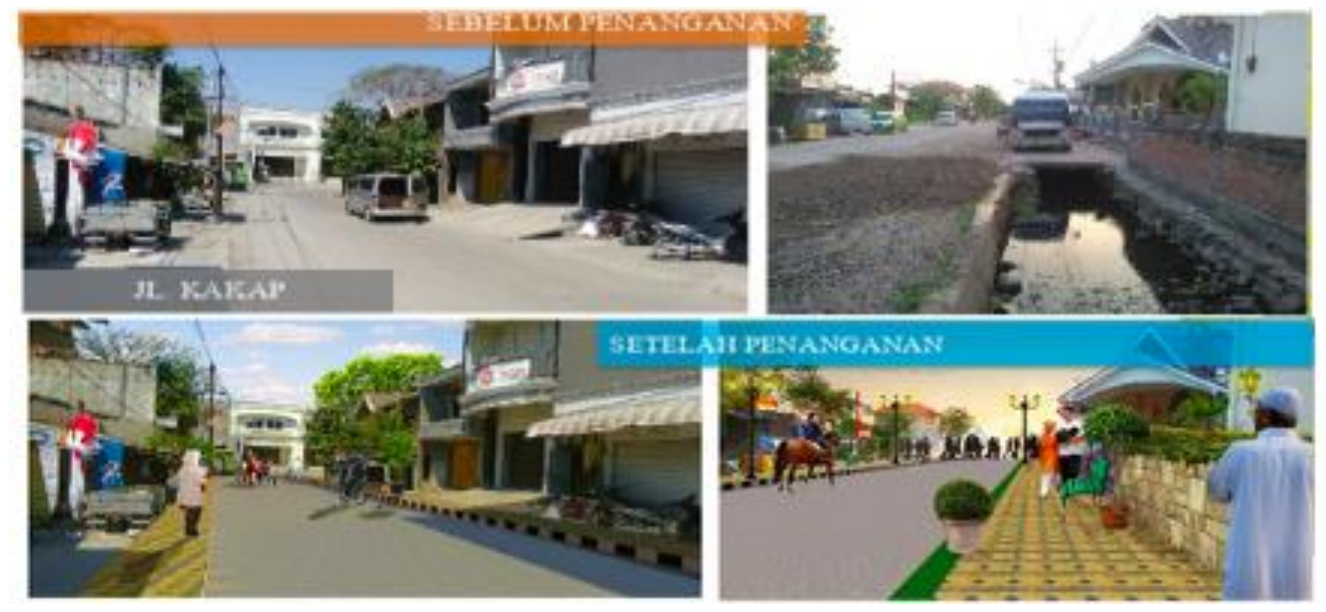

Sumber: Bappeda Kota Semarang, 2019

Gambar 4. Penanganan Akses Jalan Kakap

Gambar 4 merupakan perencanaan penanganan akses jalan di dalam Kampung Kakap. Kampung ini merupakan akses dan berada dalam jalur Kawasan PUSAKA Kota Semarang. Pemerintah juga meremajakan akses jalan kampung itu sendiri, sehingga mampu mengurangi kekumuhan dan memperindah tampilan.

Melihat upaya yang dilakukan Pemerintah Kota Semarang, dapat diketahui bahwa pemerintah tetap mengedepankan budaya dalam pembangunan yang dilakukan guna memajukan peradaban tanpa meninggalkan identitas budaya yang dimiliki. Hal ini sejalan dengan peran penting pemerintah dalam perencanaan kota, namun juga memiliki prioritas seperti urbanisasi, kemakmuran ekonomi, dan tetap memastikan kelestarian lingkungan dan budaya. Adapun cara yang ditempuh seperti halnya menciptakan tempat-tempat yang aman, bersemangat, dan layak huni, meskipun hal ini menjadi tantangan secara administratif bagi pemerintah lokal (Mirti Chand, 2018). Selaras dengan yang dilakukan oleh Pemerintah Kota Semarang, salah satu jurnal yang mengkaji tentang komunikasi pembangunan, mengungkapkan bahwa Pemerintah Kota Bogor juga mengkomunikasikan citra kota melalui bentuk tata lanskap. Konteks penelitian ini, Kota Bogor dicitrakan sebagai Kota Hijau di mana dalam mewujudkannya, dilakukan penataan taman kota yang lebih terencana (Siregar, 2019).

Tindakan yang dilakukan oleh Pemerintah Kota Semarang membuktikan bahwa pembangunan yang dilakukan diupayakan untuk tetap berorientasi pada nila-nilai budaya yang dimiliki Kota Semarang. Wilayah kumuh dapat ditangani dengan tidak mengesampingkan nilai warisan sejarah yang terkandung di dalamnya. Hal ini bahkan mampu memberikan nilai tambah untuk wilayah tersebut sebagai identitas kota yang sarat sejarah budaya.

Merujuk pada Model Pentahelix, pemerintah sebagai salah satu aktor yang berperan dalam upaya mempertahankan identitas sebuah kota idealnya dapat berkolaborasi secara maksimal dengan elemen kota lainnya, seperti akademisi, komunitas, pihak swasta, masyarakat, dan media, hanya saja sinergi yang dilakukan masih bersifat antar sektor. Hal ini dapat ditinjau dari perencanaan Kawasan Sleko Menara Syahbandar yang bermitra dengan salah satu BUMN, yaitu PT PGN. Agenda periodik pemerintah seperti musyawarah perencanaan pembangunan (musrenbang) merupakan forum lain yang dinilai efektif untuk memperkuat kolaborasi seluruh elemen kota dalam memperkuat identitas kota pada masa mendatang di tengah proyek pembangunan yang bergulir. Melalui forum tersebut, pemerintah dapat memeroleh saran konstruktif dari elemen kota lainnya, seperti akademisi, komunitas, pihak swasta, hingga masyarakat terkait program prioritas yang diusung untuk mendukung pembangunan kota, tanpa mengesampingkan identitas kota. 


\section{Peran Komunitas}

Elemen lain yang terkandung dalam Pentahelix adalah komunitas. Upaya untuk mempertahankan identitas kota sebagai "tuan rumah budaya" juga dilakukan oleh komunitas. Sekelompok pemuda Kota Semarang yang peduli terhadap isu kota menginisiasi platform Peka Kota Hub. Melalui platform ini, mereka melakukan riset mandiri tentang permasalahan yang tengah dihadapi oleh kampung-kampung asli di Kota Semarang, di tengah pesatnya pembangunan fisik. Sekelompok pemuda itu menilai bahwa kampung-kampung asli memiliki budaya lokal yang semestinya dapat mendukung identitas kota yang telah ada dan mampu menciptakan nilai tawar untuk kampung.

Berdasarkan riset mandiri tersebut, mereka kemudian menentukan sejumlah kampung yang dijadikan sebagai pilot project platform Peka Kota Hub, termasuk di antaranya adalah Kampung Bustaman - salah satu permukiman padat penduduk di Kelurahan Purwodinatan. Kampung itu dinilai mempunyai identitas unik karena citranya sebagai "kampung gulai" yang banyak melekat di benak publik. Citra tersebut muncul karena sebagian warga kampung dikenal lihai mengolah daging kambing menjadi aneka kuliner lezat, termasuk gulai kambingnya. Bersinergi dengan para pemuda kampung, platform Peka Kota Hub pun berupaya memantapkan identitas Kampung Bustaman, tanpa meninggalkan budaya lokal yang lahir dan tumbuh di sana. Proyek seni pun digagas, seperti acara "Tengok Bustaman" yang kini telah digelar secara berkala, dan dimeriahkan dengan adanya pertunjukan seni hingga wisata kuliner gulai bagi pengunjung.

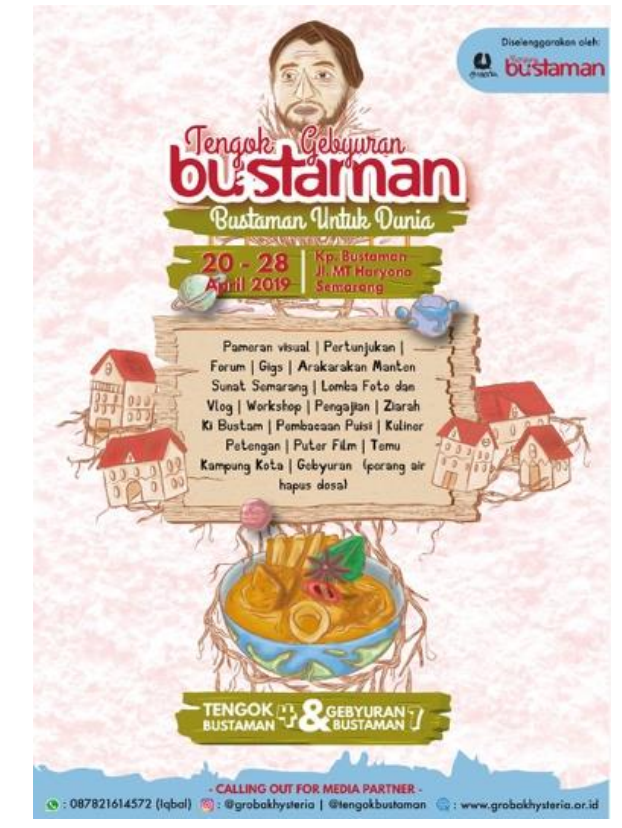

Sumber: grobakhysteria.or.id, 2019

Gambar 5. Brosur "Tengok Bustaman"

Gambar 5 adalah brosur acara tahunan "Tengok Bustaman” yang diselenggarakan oleh Peka Kota Hub untuk tahun 2019. Kegiatan yang diselenggarakan bulan April ini mengusung tema "Bustaman untuk Dunia". Tema ini diambil untuk mengingatkan kembali pada leluhur kampung, Radeng Saleh yang berkiprah sebagai penerjemah pada era Hindia Belanda, dan mendapat sebutan Kertoboso Bustaman. Jejaring kekerabatan dan silsilah serta peran leluhur inilah yang kemudian dijadikan tema besar untuk helatan ketujuh ini.

Akhmad Khoridin, salah satu pendiri platform Peka Kota Hub menjelaskan bahwa masyarakat setempat berperan sebagai aktor dalam upaya melestarikan budaya lokal, sekaligus mempertahankan identitas kota. Oleh sebab itu, warga perlu menyadari potensi yang ada di kampung mereka dan ditantang untuk mampu mengoptimalkan potensi tersebut, sehingga kampung memiliki "nilai tawar" di tengah pesatnya pembangunan fisik kota, seperti kutipan berikut:. 
"Kami selalu banyak menggunakan pintu masuk untuk kesadaran kolektifnya. Kalau mereka mengidentifikasi kampung kami adalah kampung gulai, cari data saja tentang gulai, jadi relate. Kalau berangkat dari apa yang dekat mereka, mereka akan merasa lebih memiliki dan mereka menjadi aktornya,".

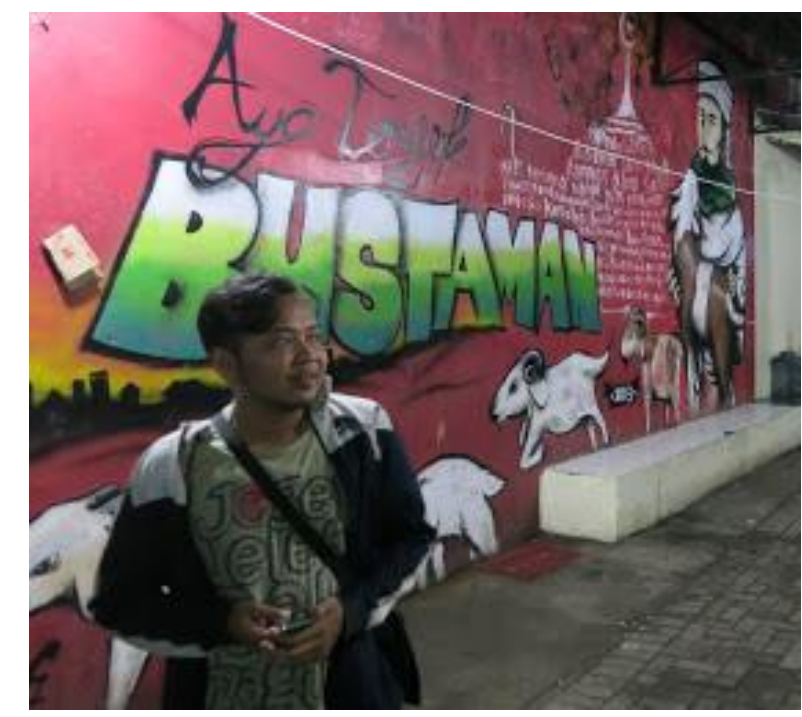

Sumber: semaranginside.com

Gambar 6. Akhmad Khoridin di Kampung Bustaman

Gambar 6 adalah sosok Akhmad Khoridin, pendiri Platform Peka Kota Hub dan Hysteria, dimana kedua platform ini saling bersinergi untuk mempertahankan budaya kampung. Tampilan kampung Bustaman yang baru juga dapat dilihat pada latar belakang, dimana terdapat foto kambing yang merupakan identitas Kampung Bustaman sebagai Kampung Gulai.

Peka Kota Hub tidak hanya mengangkat budaya yang sudah ada, namun juga menggali budaya lain, yang tidak disadari oleh masyarakat bahwa hal tersebut memiliki nilai budaya yang tinggi dan dapat menjadi daya tarik kampung. Budaya gebyuran (siram air) sebelum memasuki bulan Ramadhan ini dimulai sejak 2012.

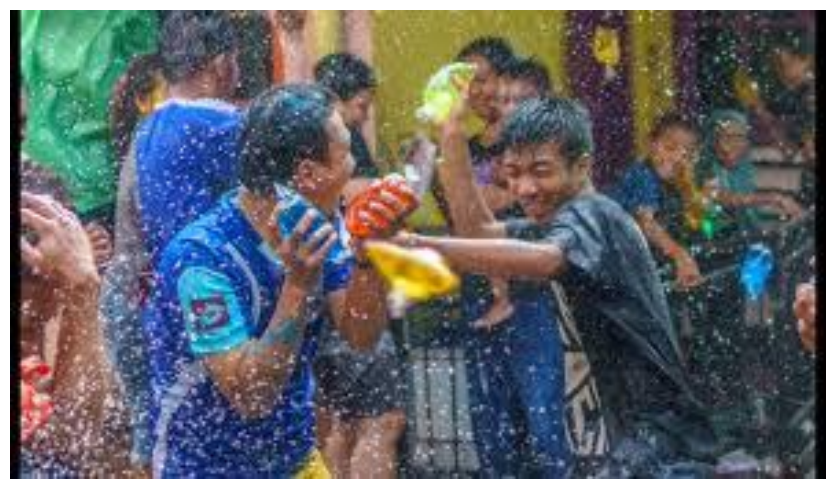

Sumber: budayajawa.id

Gambar 7. Budaya Gebyuran Bustaman

Partisipasi masyarakat adalah masalah penting dalam pengelolaan warisan budaya. Menilik pada pentingnya hal tesebut, tahun 2015 salah satu organisasi warisan internasional, ICCROM, menerbitkan dokumen pedoman yang membahas pendekatan yang berpusat pada orang untuk memenejemen warisan budaya. Partisipasi masyarakat sangat direkomendasikan dalam manajemen warisan budaya (Li, Krishnamurthy, Pereira Roders, \& van Wesemael, 2020). Partisipasi Peka Kota 
Hub sebagai platform yang fokus pada budaya kampung merupakan realisasi peran serta masyarakat dalam mengelola warisan budaya di Kota Semarang.

Program dan kegiatan platform Peka Kota Hub, sayangnya, masih dilakukan secara mandiri dan belum sepenuhnya berkolaborasi dengan para pemangku kepentingan lainnya yang terdapat pada Model Pentahelix. Kolaborasi yang minim dapat menimbulkan tidak optimalnya pencapaian tujuan yang telah ditetapkan. Sebagaimana yang dapat ditinjau dari temuan Muhyi \& Chan (2017) bahwa kurangnya kolaborasi dan komitmen dari pemangku kepentingan berdampak pada tidak optimalnya upaya untuk mengembangkan sebuah kota, baik pada tataran industri maupun bidang yang lain. Koordinasi yang belum terjalin secara efektif antara komunitas dan pemerintah misalnya, mengakibatkan program pelatihan yang telah dirancang tidak sepenuhnya tepat sasaran karena materi yang tidak sesuai dengan kebutuhan kelompok sasaran.

\section{Peran Swasta}

Bisnis di bidang pariwisata kini semakin menggeliat, seiring meningkatnya keinginan masyarakat metropolis untuk menjelajahi berbagai daerah. Bersukaria Tour, salah satu penyelenggara wisata berbasis di Kota Semarang, menggelar beberapa konsep program wisata, salah satunya dengan berjalan kaki (walking tour), di mana para pesertanya diajak untuk berkeliling ke tempat-tempat bersejarah di kota tersebut, seperti rute multikultural yang melintasi kampung-kampung etnis. Berikut kutipan hasil wawancara dengan Fauzan, Mawardi Kausar pemilik Bersukaria Tour.

"Semarang itu kota keberagaman buat kita dan kita bisa hidup rukun di kota ini. Itu yang menarik karena tidak semua kota bisa seperti ini. Rute Multikultural itu salah satunya kita menunjukkan keberagaman, perbedaan, dan mereka hidup saling berdampingan, walaupun dengan kawasan sendiri-sendiri, tetapi mereka rapat. Ada Kawasan Melayu, Eropa, Cina, dan peninggalan-peninggalan budayanya pun masih ada. Sebagian rute kami memang kampung-kampung tua sih,".

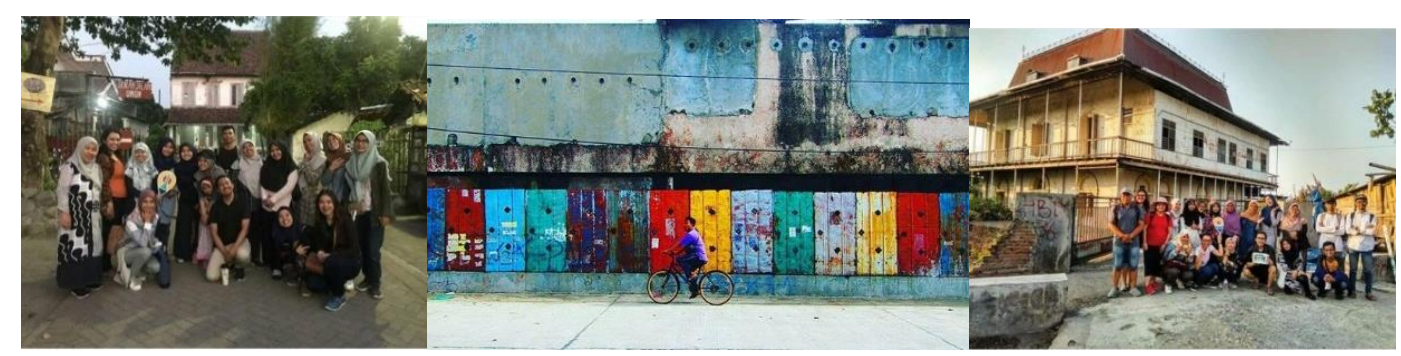

Sumber: Instagram @bersukariawalk

Gambar 8. Walking Tour Bersama Bersukaria

Rute lainnya adalah rute Kampung Kota di sekitar Kampung Sekayu, salah satu kampung yang diyakini tertua di Kota Semarang. Sepanjang perjalanan, penutur kisah (story teller) Bersukaria Tour akan bercerita tentang sejarah dan budaya yang dimiliki oleh tempat-tempat yang dilintasi, seperti keberadaan Masjid Kuno At-Taqwa yang masih mempertahankan pilar-pilar asli, meskipun masjid sudah direnovasi hingga rumah masa kecil penulis legendaris asal Kota Semarang Almarhumah NH Dini yang ada di kampung tersebut. Peserta walking tour juga dapat menyaksikan secara langsung arsitektur unik dari bangunan-bangunan setempat yang sarat makna, contohnya atap rumah berbentuk limasan, hingga nama-nama jalan berbahasa Jawa yang mencerminkan Kampung Sekayu sebagai pusat pemerintahan pada masa kerajaan silam. Uniknya, program wisata walking tour tersebut tidak mematok biaya, sehingga peserta dapat membayar secara sukarela. 


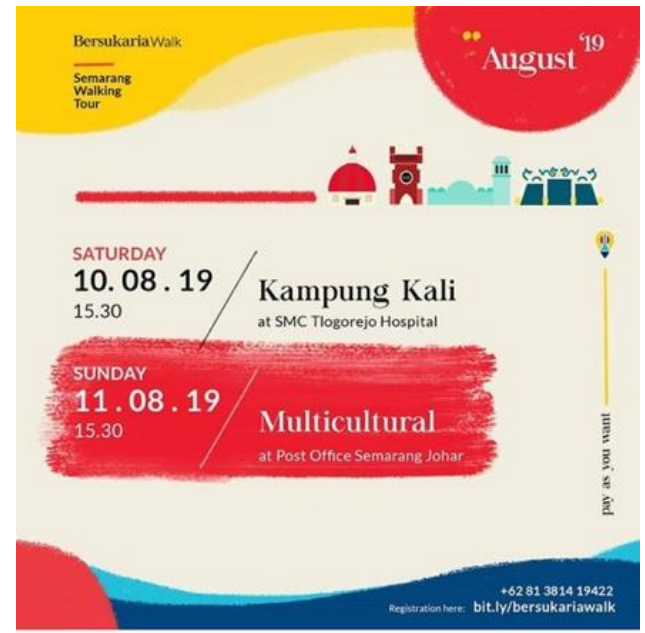

Sumber: Instagram @bersukariawalk

Gambar 9. Jadwal Bersukaria Walking Tour

Gambar 9 adalah salah satu jadwal Bersukaria walking tour. Perjalanan yang tercantum dalam poster tersebut adalah rute Kampung Kali dan Multikultural. Kedua lokasi ini merupakan lokasi perkampungan yang memiliki nilai sejarah di Kota Semarang. Adapun rute multikultural meliputi Kawasan Kota Lama, Pecinan, Kampung Melayu, Kampung Pekunden, dan Kampung India.

Meskipun tidak mengklaim sebagai penyelenggara tur sejarah, namun Bersukaria Tour turut serta dalam memperkenalkan budaya dan kisah-kisah menarik yang tumbuh di beberapa daerah di Kota Semarang, termasuk di kampung-kampung tua, seperti yang disampaikan oleh Fauzan:

"Pariwisata menjadi salah satunya (dukungan untuk mempertahankan identitas kota) dan kita bergerak di bidang itu. Misalnya kita ada tamu luar kota, city tour di Kota Semarang, mereka menjadi tahu Kota Semarang seperti apa, tahu identitas kota ini seperti apa. Saya rasa untuk identitas kota, tidak hanya di walking tour. Semua program kita untuk hal itu juga secara tidak langsung,".

Program wisata yang dicetuskan oleh Bersukaria Tour mampu memberikan kesempatan bagi turis untuk memperoleh pengalaman unik yang berkaitan dengan kehidupan lokal di suatu tempat. Hal ini selaras dengan pergeseran perspektif pariwisata pada orientasi pengalaman konsumen, yang pada gilirannya mampu memperkuat identitas suatu tempat dan membedakannya dengan tempat lain (Dahles, 1998).

Bersukaria Tour juga menjalin kemitraan dengan beberapa pihak, seperti pemerintah (Dinas Kebudayaan dan Pariwisata Kota Semarang dan Dinas Kominfo Kota Semarang) dan komunitas yaitu kelompok sadar wisata (pokdarwis), seperti dikutip:

"Kerja sama dengan pemerintah itu kita dengan Dinas Kebudayaan dan Pariwisata Kota Semarang dan terakhir kemarin dengan Dinas Kominfo Kota Semarang. Kita nemenin mereka cari spot yang anti mainstream lah. Kalau Kota Lama kan udah banyak yang angkat ya, jadi kemarin kita angkat Jatingaleh. Kita keliling bareng, mereka bikin video untuk memperkenalkan kota karena viewer mereka untuk tingkat Semarang cukup banyak. Kalau dengan teman-teman media itu beberapa kali mereka meliput. Kalau komunitas, kita sedang penjajakan dengan Pokdarwis di Tambaklorok untuk coba mengangkat daerah itu, jadi kolaborasi pariwisata sih.”.

\section{Peran Akademisi}

Akademisi berperan sebagai pusat pengetahuan yang melaksanakan Tri Dharma perguruan tinggi, yaitu pendidikan dan pengajaran, penelitian dan pengembangan, dan pengabdian masyarakat. Hal ini berarti akademisi dituntut untuk senantiasa mengembangkan bidang keilmuan mereka dengan melakukan riset yang relevan dan pendampingan terhadap masyarakat untuk membantu mengatasi 
permasalahan aktual yang dialami oleh mereka, serta menghasilkan berbagai inovasi untuk mendukung pembangunan di daerah. Hasil riset dapat digunakan sebagai bahan pertimbangan untuk pengambilan keputusan atau penyusunan kebijakan oleh pemerintah.

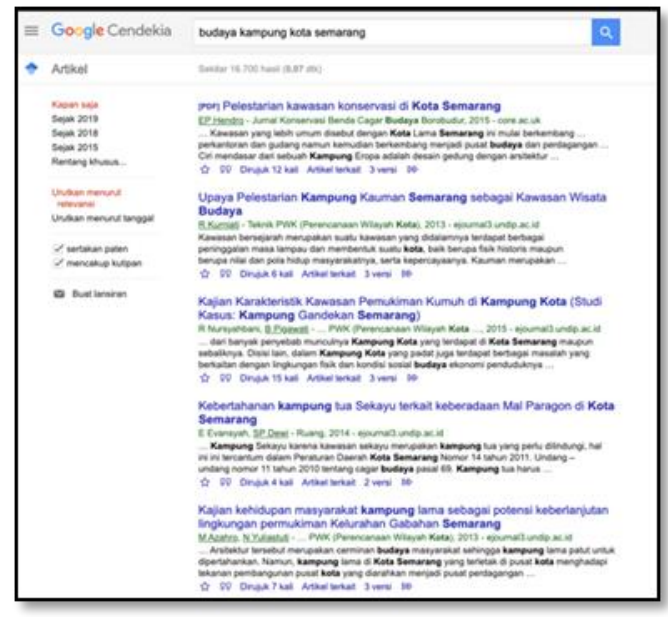

Sumber: Google Cendekia

\section{Gambar 10. Hasil Riset Akademisi}

Gambar 10 dapat memberi pandangan mengenai banyaknya penelitian yang mengkaji tentang budaya dan multikulturalisme yang ada di Kota Semarang. Hal ini bukti bahwa akademisi memberikan sumbangsih ilmu pengetahuan dan gagasan yang didasarkan pada hasil penelitian.

Dalam konteks upaya untuk mempertahankan identitas kota, akademisi dapat menyelenggarakan panel diskusi dengan para pemangku kepentingan untuk mencermati permasalahan yang dihadapi, kemudian melakukan telaah bersama guna merumuskan alternatif solusi dan rencana strategis yang dapat diimplementasikan. Sebagai contoh, Focus Group Discussion (FGD) Dewan Pertimbangan Pembangunan Kota (DP2K) Semarang di Balai Kota Semarang pada Desember 2017 lalu. Akademisi hadir untuk mengulas secara mendalam tentang upaya mendukung city branding Kota Semarang bersama narasumber lainnya. Dalam forum tersebut, akademisi menjelaskan bahwa city branding tidak sebatas menggunakan logo dan slogan yang tepat untuk suatu kota, namun lebih kepada mempertimbangkan karakter yang paling tepat untuk merepresentasikan Kota Semarang sebagai entitas merek. City branding yang sukses tidak hanya menentukan positioning kota, namun mampu membuat masyarakat merasa ikut memiliki sebuah kota, dan berdampak pula pada perkembangan investasi setempat.

Kemitraan yang dijalin melalui kesepakatan bersama antara perguruan tinggi dan Pemerintah Kota Semarang perihal pelaksanaan Tri Dharma pergurunan tinggi merupakan salah satu upaya untuk memajukan pembangunan kota. Melalui kesepakatan bersama tersebut, pemerintah mendukung akademisi untuk meningkatkan kajian strategis selaras dengan bidang keilmuannya, seperti pengembangan tata kota, infrastruktur, hingga perekonomian yang diwujudkan melalui pendampingan usaha mikro, kecil, dan menengah (UMKM) (Fardianto, 2019). 


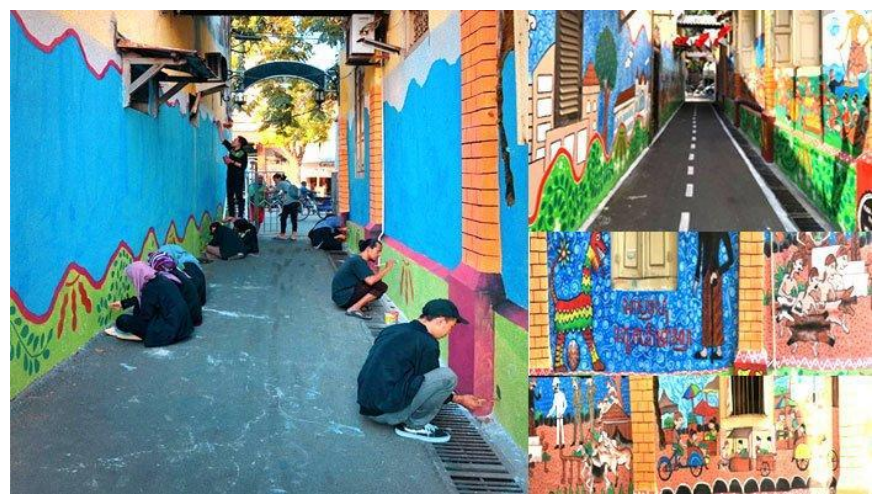

Sumber: TribunJateng.com

Gambar 11. Mahasiswa KKN Unnes Merevitalisasi Kampung Kulitan

Upaya untuk mempertahankan identitas kota juga dapat dilakukan melalui implementasi program kuliah kerja nyata $(\mathrm{KKN})$ tematik di kampung-kampung yang ada di Kota Semarang. Sebagai contoh, mahasiswa Universitas Negeri Semarang melakukan KKN di Kampung Kulitan, salah satu kampung bersejarah di Kelurahan Jagalan. Mereka merevitalisasi kampung tersebut agar semakin cantik dengan mural art yang mengisahkan tentang sejarah dan potensi kampung, yaitu tentang tuan tanah legendaris di Kota Semarang pada masa penjajahan Belanda, bernama Tuan Tasripin, yang biasa menguliti sapi dan kambing untuk digunakan sebagai bahan kerajinan tas, sepatu, ikat pinggang, dan lainnya (Imanulhaq, 2019).

Tidak hanya secara langsung melalui KKN, akademisi juga mampu memberikan sumbangsih melalui hasil penelitian. Hal ini selaras dengan fungsi science arbitier, di mana para ilmuwan menjadi narasumber ilmiah untuk pengambil kebijakan. Akademisi biasanya fokus pada satu isu atau masalah yang membutuhkan pemecahan melalui ilmu pengetahuan. Policy advocate juga mengakui bahwa ilmu pengetahuan harus dikaitkan dengan para pengambil kebijakan, sehingga akademisi turut berperan dalam perumusan kebijakan guna kepentingan bersama. Fungsi lain akademisi adalah honest broker of policy alterbatives, yaitu akademisi terlibat secara langsung dalam pengambilan kebijakan guna mengklarifiasi dan memperluas cakupan pilihan kebijakan (Nurfatriani, Darusman, Nurrochmat, Yustika, \& Salaka, 2018).

\section{Peran Media}

Kiprah media dalam mempertahankan identitas kota dapat dilakukan dengan cara menyelenggarakan forum diskusi untuk mengulas persoalan yang tengah dihadapi oleh kampungkampung asli di Kota Semarang di tengah pesatnya pembangunan fisik, seperti focus group discussion (FGD) yang diselenggarakan oleh Forum Wartawan Balai Kota (Forwakot) Semarang dengan tema "Peran Pemikir dalam Pembangunan Daerah (Kado Intelektual M Farchan)" di HOC Café pada April 2019. FGD tersebut menghadirkan sejumlah narasumber dari unsur pemerintah (Bappeda Kota Semarang) hingga redaktur untuk merumuskan alternatif solusi dari persoalan tersebut. 


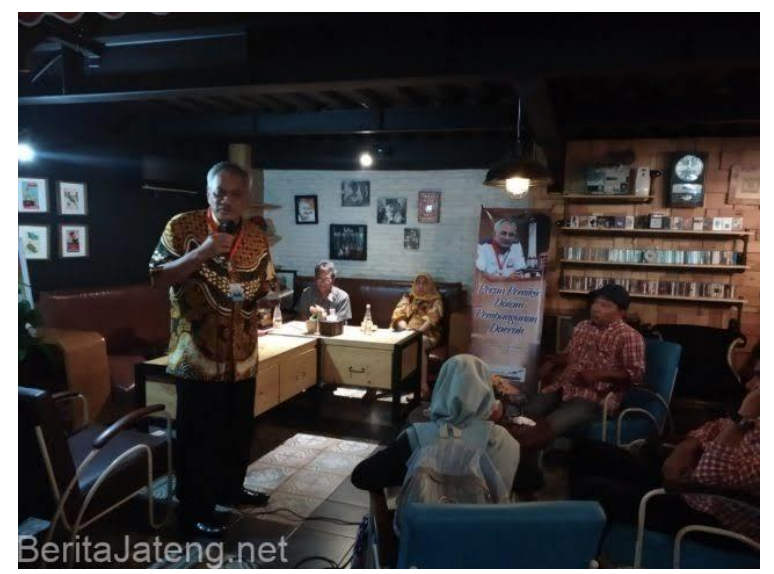

Sumber: BeritaJateng.net

Gambar 12. FGD Forum Wartawan Kota (Forwakot) Semarang

Tidak dapat dipungkiri bahwa media menjalankan fungsi sebagai penentu agenda (agenda setting), sehingga publikasi berita yang mereka lakukan dapat mengarahkan audiens untuk memberikan perhatian pada isu-isu tertentu yang aktual atau relevan dengan kepentingan mereka. Ketika media mempublikasikan berita tentang persoalan yang dihadapi oleh kampung-kampung asli di Kota Semarang di tengah pesatnya pembangunan fisik, maka diharapkan dapat menarik perhatian audiens sehingga mereka turut peduli terhadap persoalan tersebut. Sebagai contoh adalah publikasi berita berjudul "Kampung Historis di Semarang Kian Punah" pada Republika.com (Putra, 2019).

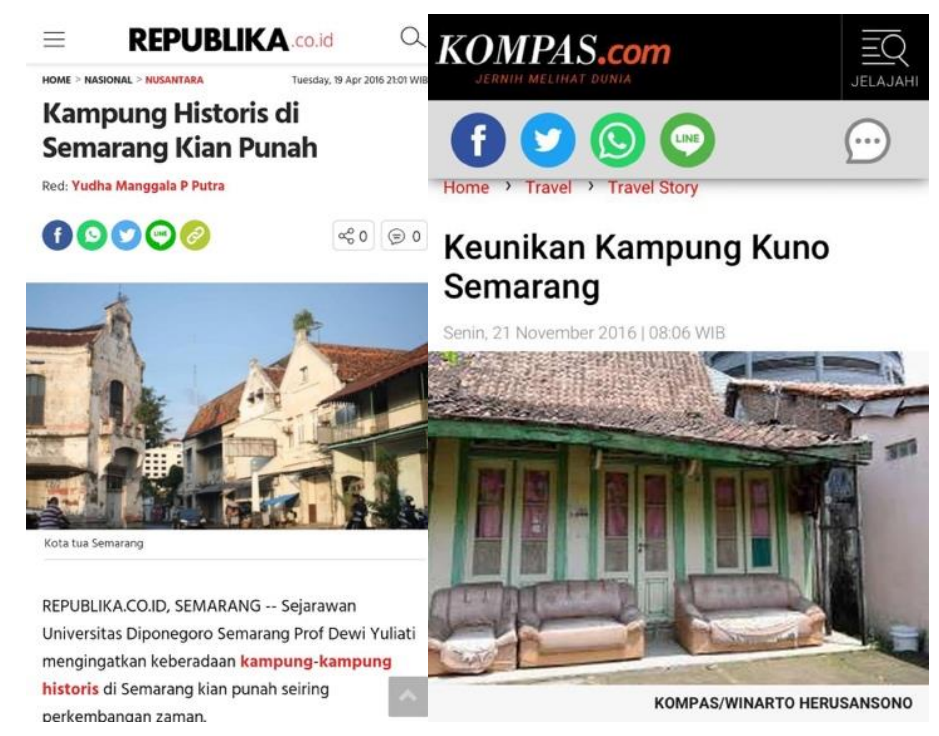

Sumber: Google Browser

Gambar 13. Publikasi Media tentang Kampung Kuno di Kota Semarang

Media lain yang juga berperan untuk meningkatkan wawasan pembaca, sekaligus membantu menginternalisasikan nilai-nilai budaya dari satu generasi ke generasi berikutnya adalah Kompas.com. Melalui publikasi berita tentang sejarah unik masing-masing kampung di Kota Semarang, diharapkan wawasan pembaca bertambah, sekaligus dapat menginternalisasikan nilai-nilai budaya kepada para pembaca muda. Masih banyak lagi media daring yang memberikan kontribusi dalam mempublikasikan artikel-artikel mengenai budaya yang ada di Kota Semarang.

Media massa memiliki peran penting dalam membentuk persepsi publik, termasuk citra yang dibangun tentang suatu tempat. Publikasi yang bersifat positif mampu memberikan citra positif yang 
melekat pada suatu tempat. Berlaku sebaliknya, publikasi atau pemberitan yang negatif mampu memunculkan citra negatif pula pada suatu tempat (Freeman \& Nhung Nguyen, 2012). Berdasar hal ini, peran serta media dalam memberitakan tentang budaya kampung di Kota Semarang idealnya juga mampu memberikan dampak positif pada citra kampung dan mampu menumbuhkan opini masyarakat tentang pentingnya budaya kampung terkait.

Berdasarkan uraian di atas, diketahui bahwa sinergi dan kolaborasi para pemangku kepentingan yang tercantum pada Model Pentahelix untuk mempertahankan identitas kota belum maksimal. Upaya yang ditempuh masing-masing elemen kota masih bersifat parsial melalui kerja sama antar sektor. Misalnya kerja sama antara pemerintah dan swasta, pemerintah dan media, swasta dan komunitas. Untuk itu, pada masa mendatang diperlukan penguatan sinergi dan kolaborasi untuk mempertahankan identitas kota, seperti menginisiasi dan mengimplementasikan sebuah program terpadu lintas sektor yang mampu menjaring kertelibatan aktif segenap elemen kota.

\section{KESIMPULAN}

Akademisi sebagai sumber pengetahuan memiliki konsep dan teori yang dapat didayagunakan untuk menciptakan berbagai inovasi bermanfaat bagi pembangunan daerah. Pemerintah sebagai regulator mencanangkan peraturan atau kebijakan, sekaligus bertanggung jawab untuk memastikan bahwa aktivitas warga dan institusi lainnya telah menaati regulasi yang ditetapkan. Pihak swasta melaksanakan serangkaian aktvitas bisnis yang berpengaruh terhadap perputaran roda ekonomi di daerah. Komunitas adalah sekelompok orang yang memiliki minat dan kepentingan sama terhadap bidang tertentu. Terakhir, media bertanggung jawab menyediakan informasi publik yang akurat, sekaligus sebagai agen kontrol sosial yang turut mengawasi pelaksanaan pembangunan.

Rampersad, Quester, \& Troshanir (2009) mengemukakan bahwa kolaborasi pentahelix memiliki peran penting dalam mendukung tujuan inovasi bersama dan berkontribusi pada kemajuan sosial-ekonomi di suatu wilayah. Artinya, apabila kelima sektor tersebut dapat bersinergi secara maksimal, maka besar kemungkinan harapan pembangunan berkelanjutan di berbagai bidang dapat terwujud.

Meski demikian, hasil penelitian menunjukkan bahwa kolaborasi dan kerjasama kelima elemen kota yang ada pada Model Pentahelix belum maksimal. Para pemangku kepentingan masih berjalan pada upaya masing-masing dan belum mengintegrasikan upaya tersebut dengan sektor lainnya. Adapun rangkulan dari pemerintah kepada akademisi belum mencerminkan kolaborasi utuh yang dapat dijelaskan melalui Model Pentahelix. Berdasar kondisi tersebut, saran yang diberikan adalah perlunya penguatan kerjasama antar sektor. Kegiatan-kegiatan diskusi yang mendukung juga tidak kalah penting untuk secara periodik dilaksanakan, bahkan jika memungkinkan hal ini dapat

difasilitasi oleh pemerintah karena mempertahankan budaya kampung sebagai identitas Kota Semarang merupakan pekerjaan rumah setiap elemen kota.

\section{UCAPAN TERIMA KASIH}

Terima kasih peneliti tujukan kepada pihak-pihak yang telah mendukung penelitian ini, yaitu Bappeda Kota Semarang, Peka Kota Hub, dan CV. Bersukaria Walk \& Tour.

\section{DAFTAR PUSTAKA}

Amar, A. (2009). Identitas Kota, Fenomena Dan Permasalahannya. Ruang: Jurnal Arsitektur, 1(1), $55-59$.

Annas, F. B., \& Irwansyah. (2008). Membangun Identitas Merek Kota Bogor Melalui We Love Bogor di Instagram. PIKOM, 19(2).

Asdhiana, I. M. (2016). Keunikan Kampung Kuno Semarang. Retrieved November 17, 2019, from 
KOMPAS.com

website:

https://kilasdaerah.kompas.com/jatenggayeng/read/2016/11/21/080600227/keunikan.kampung.kuno.semarang

Azra, A. (2015). Pembangunan dan Peradaban. Retrieved November 19, 2019, from KOMPAS.com website:

https://nasional.kompas.com/read/2015/11/10/17000091/Pembangunan.dan.Peradaban?page=all

Bappeda Pemkot Semarang. (2019). Laporan Pendampingan Program Kotaku Kota Semarang Ta. 2018. Semarang.

Braun, E., Kavaratzis, M., \& Zenker, S. (2013). My city - my brand: The different roles of residents in place branding. Journal of Place Management and Development, 6(1), 18-28. https://doi.org/10.1108/17538331311306087

Carlo, M., Canali, S., Pritchard, A., \& Morgan, N. (2009). Moving Milan towards Expo 2015: Designing culture into a city brand. Journal of Place Management and Development, 2(1), 8-22. https://doi.org/10.1108/17538330910942762

Cecilia. (2016). Beragam Budaya Kota Semarang yang Perlu Diketahui. Retrieved November 19, 2019, from semberani.com website: https://www.semberani.com/beragam-budaya-kotasemarang-yang-perlu-diketahui/

Dahles, H. (1998). Redefining Amsterdam as a tourist destination. Annals of Tourism Research, 25(1), 55-69. https://doi.org/10.1016/s0160-7383(97)00061-3

Damanik, C. (2016). Akibat Ekspansi Mal dan Hotel, Kampung Asli di Semarang Terancam. Retrieved November 15, 2019, from KOMPAS.com website: https://regional.kompas.com/read/2016/11/08/12342021/akibat.ekspansi.mal.dan.hotel.kampung. asli.di.semarang.terancam

Dani, M. U., \& Hidayat, S. (2019). Semarang Raoh 2 Penghargaan di Musrenbang 2019. Retrieved November 19, 2019, from GATRA.com website: https://www.gatra.com/detail/news/415111/politik/semarang-raih-2-penghargaan-dimusrenbang-2019

Evans, G. (2009). Creative cities, creative spaces and urban policy. In Urban Studies (Vol. 46). https://doi.org/10.1177/0042098009103853

Fajlin, E. Y. (2019). Kampung Kuno di Kota Semarang Terdesak Pembangunan, Kampung Sekayu Harus Dipertahankan. Retrieved November 17, 2009, from TribunJateng.com website: https://jateng.tribunnews.com/2019/04/03/kampung-kuno-di-kota-semarang-terdesakpembangunan-kampung-sekayu-harus-dipertahankan

Fardianto, F. (2019). Walikota Semarang Rangkul Akademisi untuk Kembangkan Desain Tata Kota. Retrieved November 18, 2019, from IDN Times Jateng website: https://jateng.idntimes.com/news/jateng/fariz-fardianto/walikota-semarang-rangkul-akademisiuntuk-kembangkan-desain-tata-kota

Freeman, B. C., \& Nhung Nguyen, T. (2012). Seeing Singapore: Portrayal of the city-state in global print media. Place Branding and Public Diplomacy, 8(2), 158-169. https://doi.org/10.1057/pb.2012.10

Freire, J. R. (2009). Local people a critical dimension for place brands. Journal of Brand Management, 16(7), 420-438. https://doi.org/10.1057/palgrave.bm.2550097

Giovanardi, M., Lucarelli, A., \& Pasquinelli, C. (2013). Towards brand ecology: An analytical semiotic framework for interpreting the emergence of place brands. Marketing Theory, 13(3), 365-383. https://doi.org/10.1177/1470593113489704

Hadiyanto. (2008). Komunikasi Pembangunan Partisipatif: Sebuah Pengenalan Awal. Jurnal Komunikasi Pembangunan, 6(2).

Hayden, C., \& Sevin, E. (2012). The politics of meaning and the city brand: The controversy over the branding of Ankara. Place Branding and Public Diplomacy, 8(2), 133-146. https://doi.org/10.1057/pb.2012.8

Humas Pemprov Jawa Tengah. (2019). Kelola Keragaman Budaya untuk Selesaikan Masalah. Retrieved November 19, 2019, from jatengprov.go.id website: https://jatengprov.go.id/publik/kelola-keragaman-budaya-untuk-selesaikan-masalah/

Imanulhaq, A. (2019). Pelestarian Potensi Cagar Budaya Kampung Kulitan oleh Mahasiswa KKN Unnes. Retrieved November 15, 2019, from TribunJateng.com website: https://jateng.tribunnews.com/2019/08/19/pelestarian-potensi-cagar-budaya-kampung-kulitan- 
oleh-mahasiswa-kkn-unnes

Kavaratzis, M., \& Hatch, M. J. (2013). The dynamics of place brands: An identity-based approach to place branding theory. Marketing Theory, 13(1), 69-86. https://doi.org/10.1177/1470593112467268

Kavaratzis, M., \& Kalandides, A. (2015). Rethinking the place brand: the interactive formation of place brands and the role of participatory place branding. Environment and Planning A, 47(6), 1368-1382. https://doi.org/10.1177/0308518X15594918

Lalli, M. (1992). Urban-related identity: Theory, measurement, and empirical findings. Journal of Environmental Psychology, 12(4), 285-303. https://doi.org/10.1016/S0272-4944(05)80078-7

Li, J., Krishnamurthy, S., Pereira Roders, A., \& van Wesemael, P. (2020). Community participation in cultural heritage management: A systematic literature review comparing Chinese and international practices. Cities. https://doi.org/10.1016/j.cities.2019.102476

Mirti Chand, A. V. (2018). Place Based Approach to plan for Resilient Cities: A local government perspective. Procedia Engineering, 212, 157-164. https://doi.org/10.1016/j.proeng.2018.01.021

Montalto, V., Tacao Moura, C. J., Langedijk, S., \& Saisana, M. (2019). Culture counts: An empirical approach to measure the cultural and creative vitality of European cities. Cities, 89(March 2018), 167-185. https://doi.org/10.1016/j.cities.2019.01.014

Muhyi, H. A., \& Chan, A. (2017). The Penta Helix Collaboration Model in Developing Centers of Flagship Industry in Bandung City. Review of Integrative Business and Economics Research, $6(1), 412$.

Nurfatriani, F., Darusman, D., Nurrochmat, D. R., Yustika, A. E., \& Salaka, F. (2018). Peran Ilmuwan Dalam Pembuatan Kebijakan Fiskal Hijau : Studi Kasus Provinsi Jambi. 15(1), 39-54.

Pratt, A. C. (2011). The cultural contradictions of the creative city. City, Culture and Society, 2(3), 123-130. https://doi.org/10.1016/j.ccs.2011.08.002

Pujakesuma, A. (2019). Investasi Semester Pertama Semarang Capai Rp 15,94 Triliun. Retrieved November 17, 2019, from merdeka.com website: https://semarang.merdeka.com/kabarsemarang/investasi-semester-pertama-semarang-capai-rp1594-triliun-190813s.html

Putra, Y. M. P. (2019). Kampung Historis di Semarang Kian Punah. Retrieved November 15, 2019, from Republika.co.id website: https://www.republika.co.id/berita/dunia-islam/islamnusantara/17/05/25/nasional/daerah/16/04/19/o5vvzg284-kampung-historis-di-semarang-kianpunah

Rampersad, G., Quester, P., \& Troshanir, I. (2009). Management of networks involving Technology Transfer from public to private sector: a conceptual framework. International Journal Technology Transfer and Commersialitation, 8(2/3), 121-141.

Rhismawati, N. L. (2018). Presiden: Pembangunan Infrastruktur Bagian dari Pembangunan Peradaban. Retrieved November 15, 2019, from ANTARANEWS.com website: https://www.antaranews.com/berita/720661/presiden-pembangunan-infrastruktur-bagian-daripembangunan-peradaban

Rizzo, I., \& Throsby, D. (2006). Chapter 28 Cultural Heritage: Economic Analysis and Public Policy. Handbook of the Economics of Art and Culture, 1(06), 983-1016. https://doi.org/10.1016/S1574-0676(06)01028-3

Sarvaes, J. (2003). Approaches to Development: Studies on Communication for Development. Paris: UNESCO.

Siregar, M. R. A. (2019). Komunikasi Kota Ruang Publik Taman Sebagai Pembentuk Citra Kota Hijau. Jurnal Komunikasi Pembangunan, 17(1), 102-113. https://doi.org/10.29244/jurnalkmp.17.1.102-113

Sugiarto, Siagian, D., Sunaryanto, L. T., \& Oetomo, D. S. (2003). Teknik Sampling. jakarta: PT. Gramedia Pustaka Utama.

Wang, S., \& Chen, J. S. (2015). The influence of place identity on perceived tourism impacts. Annals of Tourism Research, 52, 16-28. https://doi.org/10.1016/j.annals.2015.02.016

Winarni, F. (2018). Aspek Hukum Peran Serta Masyarakat Dalam Pelestarian Cagar Budaya. Mimbar Hukum - Fakultas Hukum Universitas Gadjah Mada, $30(1), \quad 94$. https://doi.org/10.22146/jmh.29160

Yin, R. K. (2009). Case Study Research: Design and Methods. In L. Bickman \& D. J. Rog (Eds.), Essential guide to qualitative methods in organizational research. 
https://doi.org/10.1097/FCH.0b013e31822dda9e

Yuningsih, T., Darmi, T., \& Sulandari, S. (2019). Model Pentahelik Dalam Pengembangan Pariwisata Di Kota Semarang. JPSI (Journal of Public Sector Innovations), 3(2), 84. https://doi.org/10.26740/jpsi.v3n2.p84-93 